\title{
Flavonoids, phenolic content, and antioxidant activity of propolis from various areas of Guanajuato, Mexico
}

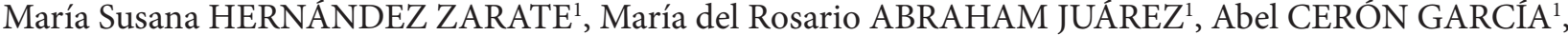 \\ César OZUNA LÓPEZ ${ }^{1}$, Abner Josué GUTIÉRREZ CHÁVEZ², \\ José de Jesús Nezahualcóyotl SEGOVIANO GARFIAS³, Fidel AVILA RAMOS²
}

\begin{abstract}
Propolis is a resin gathered by honey bees from trees and shrubs but it used in the beehive as building material or as an antibiotic paste. The aim of this study was to determine the content of flavonoids and phenols, as well as the antioxidant capacity of propolis from various regions of Guanajuato, Mexico. The content of flavonoids and phenols was determined by the aluminum nitrate method and the Folin-Ciocalteu method. The antioxidant capacity was determined using the free radical 2,2-diphenyl-1-picrylhydrazyl (DPPH•) method and the ferric reduction of Fe3+ to Fe2+ (FRAP•) assay. The flavonoid content varied from 13 to $379 \mathrm{mg}$ of quercetin equivalents (QE) per g of propolis and the phenolic content ranged from 68 to $500 \mathrm{mg}$ of caffeic acid equivalents (CAE) per $\mathrm{g}$ of propolis. The trolox equivalent antioxidant capacity (TEAC) per g of propolis varied from 39.8 to 54.4 for the DPPH• method and from 50 to 2000 for the FRAP• assay. Propolis rich in flavonoids and phenols possesses a low antioxidant capacity. The results show that propolis from different areas of Guanajuato are rich in flavonoids and phenolics compounds while their antioxidant capacity is variable.
\end{abstract}

Keywords: antioxidant capacity; DPPH•; FRAP•; natural antioxidants.

Practical Application: Food applications as an additive agent in processed foods for humans or animals.

\section{Introduction}

Propolis are produced by honey bees from resins gathered from trees, shrubs, and other plants. Bees use this substance as a building material to cover up cracks in the beehive, to regulating the humidity and temperature their nest, also use them as antibiotic pastes (Simone-Finstrom \& Spivak, 2010). For this reason, the chemical composition of propolis varies depending on its origin. More than 240 propolis-containing substances have been identified (Lustosa et al., 2008; Huang et al., 2014), many of them with anti-carcinogenic, anti-inflammatory, antimicrobial and antioxidant properties (Kouidhi et al., 2010; Valente et al., 2011; Frozza et al., 2013).

Free radical activity, chemical factors and physical are responsible for cell aging, this physiological process causes pathological conditions such as cardiovascular disease, cancer, diabetes, arthritis, Parkinson's, and Alzheimer's disease, among others (Bennett, 1999; Vera-Ramirez et al., 2011; Maxwell \& Lip, 1997). Antioxidant agents can serve as defensive factors against free radicals in the human body (Wojtunik-Kulesza et al., 2016). Enzymes as superoxide dismutase, catalase, and glutathione peroxidase comprise the main defense system against oxidation (Lei et al., 2007). If the production of free radicals exceeds the response capacity of the enzyme system in the human body, the second line to defense is constituted by vitamins. For example, vitamin $\mathrm{C}$ and $\mathrm{E}$ can scavenge free radicals and inactivate them by oxidation (McCay, 1985). Finally, if both defense mechanisms are overcome, major damages at the cellular level are generated.

Flavonoids and phenolic compounds are important components of propolis, both substances have proven their ability to remove (or deactivate) free radicals, on top of being able to protect lipids and vitamin $C$ from being destroyed in the oxidative process (Attia et al., 2012; Frozza et al., 2013). By this characteristic, propolis has gained popularity among consumers, nowadays it is added to drinks, foods, cosmetics, and even to chewing gum or toothpaste (Valente et al., 2011; Silva et al., 2013). Its broad spectrum, its biological properties and multiple applications have given rise to interest in investigating their characteristic according their origin. A lot of studies indicate that flavonoids and phenols in propolis can be able to scavenge free radicals in the human body (Padmavathi et al., 2006; Wu et al., 2011; Vongsak et al., 2015).

There are colorimetric methods used to determine the content of phenols and flavonoids at propolis. These methods are used to estimate the content of active compounds in propolis 
quantitatively in many countries. Furthermore, the same principle is used to determine their antioxidant capacity. Therefore, the aim of this investigation was to determine the amount of flavonoids, phenols and antioxidant activity of propolis from various regions of Guanajuato, Mexico.

\section{Materials and methods}

\subsection{Materials}

Whatman ${ }^{\circledast}$ filter papers number $541,0.40 \mu$, (Buckinghamshire, United Kingdom), Acrodisc ${ }^{\circledR}$ syringe filter, PALL, (Arbor, USA), 2,2-diphenyl-1-picrylhydrazyl, D9132 Sigma-Aldrich (Toluca, Mexico), Perkin Elmer spectrophotometer, Lambda XLS, (United Kingdom), trolox, 6-hydroxy-2,5,7,8-tetramethylchroman-2-carboxylic acid, Sima-Aldrich, (Toluca, Mexico), quercetin Sigma-Aldrich, (Toluca, Mexico), Folin-Ciocalteu 2M, Sigma-Aldrich (Toluca, Mexico), TPZ, 2,4,6-Tris(2-pyridyl)-s-triazine Sigma-Aldrich (Toluca, Mexico), butylhydroxytoluene (BHT), Sigma-Aldrich, (Toluca, Mexico), iron(III) chloride hexahydrate, $\mathrm{FeCL}_{3} \cdot 6 \mathrm{H}_{2} \mathrm{O}$, Meyer, (Mexico City, Mexico).

\subsection{Origin of propolis}

The propolis samples were collected from honey-bee colonies located in 11 municipalities of beekeeping areas of the state of Guanajuato during the months of June, July, and August 2015 (Figure 1). The minimum distance between the apiaries used for the collection were $5 \mathrm{~km}$, the samples were stored frozen $\left(-20^{\circ} \mathrm{C}\right)$ until they were used ( 20 days).

\subsection{Propolis extract preparation}

Propolis ( $1 \mathrm{~g}$ ) was placed in $25 \mathrm{~mL}$ of $80 \%$ ethanol and constantly stirred for $48 \mathrm{~h}$ at $20^{\circ} \mathrm{C}$, protected from light. The mixture was stored at $-20{ }^{\circ} \mathrm{C}$ for $24 \mathrm{~h}$ and subsequently filtered twice: first at $0.40 \mu \mathrm{m}$ and then at $0.22 \mu \mathrm{m}$. Once filtered, the ethanol extracts of propolis (EEP) were concentrated in a rotary evaporator under reduced pressure at $40{ }^{\circ} \mathrm{C}$, and the

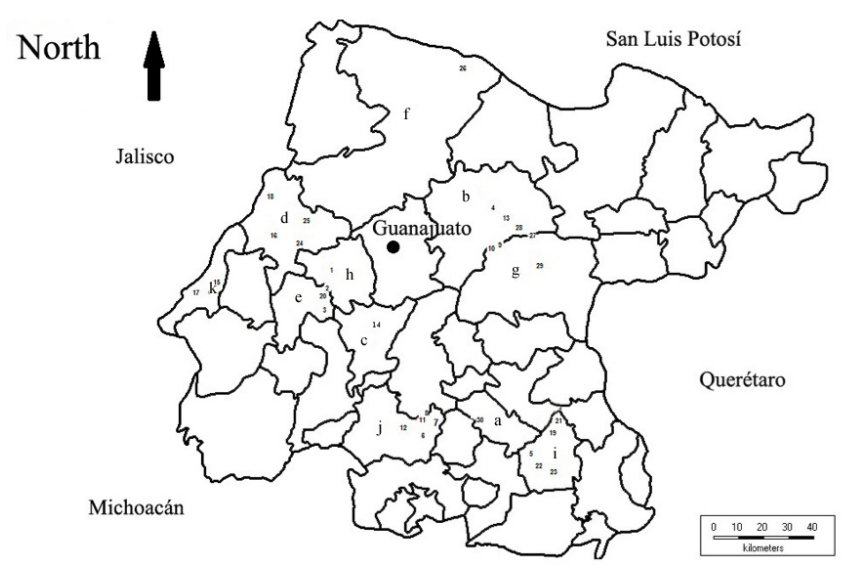

Figure 1. Propolis collection sites. Locations and municipalities of the state of Guanajuato, Mexico. a. Cortazar, b. Dolores Hidalgo, c. Irapuato, d. León, e. Romita, f. San Felipe, g. San Miguel de Allende, h. Silao, i. Tarimoro, j. Valle de Santiago. k. Purisima del Rincón. dry propolis residues were dissolved at the same concentration before their used.

\subsection{Flavonoid content (the aluminum nitrate method)}

$\operatorname{EEP}(50 \mu \mathrm{l})$ were placed in tubes containing $950 \mu \mathrm{L}$ of $80 \%$ of ethanol, and $500 \mu \mathrm{l}$ of this solution was mixed with $100 \mu \mathrm{L}$ of $10 \% \mathrm{AlCl}_{3}, 100 \mu \mathrm{L} 1 \mathrm{M}$ of $\mathrm{CH}_{3} \mathrm{CO}_{2} \mathrm{~K}$ and $4 \mathrm{~mL}$ of $\mathrm{CH}_{3} \mathrm{CH}_{2} \mathrm{OH}$ $(80 \%)$. The resulting mixture was allowed to rest for $40 \mathrm{~min}$ at $20{ }^{\circ} \mathrm{C}$. After that, the absorbance at $415 \mathrm{~nm}$ was measured. Each sample of propolis was measured five times, the flavonoid content was expressed in $\mathrm{mg}$ of quercetin equivalents (QE) per $g$ of propolis. The standard curve was generated using a concentration of $1 \mathrm{mg}$ quercetin $\left(r^{2}=0.9973\right)$.

\subsection{Phenolic content (the Folin-Ciocalteu method)}

EEP $(10 \mu \mathrm{L})$ were dissolved in $0.5 \mathrm{~mL}$ of $2 \mathrm{M}$ Folin-Ciocalteu ( $5 \mathrm{~mL}$ in $45 \mathrm{~mL}$ of $\mathrm{H}_{2} \mathrm{O}$ ), then $2 \mathrm{~mL}$ of $1 \%(\mathrm{p} / \mathrm{v}) \mathrm{Na}_{2} \mathrm{CO}_{3}$ aqueous solution were added. The resulting mixture was allowed to rest for $2 \mathrm{~h}$ at $20^{\circ} \mathrm{C}$, protected from light. After that, the absorbance at $765 \mathrm{~nm}$ was measured, each sample of propolis was measured five times, the phenolic content was expressed in mg of caffeic acid equivalents (CAE) per $g$ of propolis. The standard curve was generated using a concentration of $500 \mu \mathrm{g}$ per $\mathrm{mL}$ of caffeic acid $\left(r^{2}=0.9974\right)$.

\subsection{Antioxidant capacity (the DPPH・ method)}

DPPH• solution $(7.5 \mathrm{mg} / 100 \mathrm{~mL})$ was prepared in $80 \%$ $\mathrm{CH}_{3} \mathrm{CH}_{2} \mathrm{OH}$ with constant stirring for $10 \mathrm{~min}$. EEP $(10 \mu \mathrm{L})$ were added to $1990 \mu \mathrm{L}$ of the DPPH. solution; the sample was homogenized with vortex stirring, and the resulting mixture was allowed to rest for $30 \mathrm{~min}$ at $20^{\circ} \mathrm{C}$, protected from light. After that, the absorbance at $517 \mathrm{~nm}$ was measured, each sample of propolis was measured five times, the anti-radical activity was expressed as trolox equivalent antioxidant capacity (TEAC) per $g$ of propolis. The standard curve was generated using a concentration of $25 \mu \mathrm{g}$ per $\mathrm{mL}$ of trolox $\left(\mathrm{r}^{2}=0.9953\right)$.

\subsection{Antioxidant capacity (the FRAP• method)}

Three solutions were prepared; solution 1, $300 \mu \mathrm{M}$ pH 3.8 acetate buffer, was prepared by diluting $3.120 \mathrm{~g}$ of $\mathrm{C}_{2} \mathrm{H}_{3} \mathrm{NaO}_{2}$ and $16 \mathrm{~mL}$ of $\mathrm{CH}_{3} \mathrm{COOH}$ in $1 \mathrm{~L}$ of distilled $\mathrm{H}_{2} \mathrm{O}$. For solution 2, $0.031 \mathrm{~g}$ of TPTZ was dissolved in $10 \mathrm{~mL}$ of $\mathrm{HCl}, 1.46 \mathrm{~mL}$ of $\mathrm{HCl}(36.46 \mathrm{~mol})$ was added to $1 \mathrm{~L}$ of distilled $\mathrm{H}_{2} \mathrm{O}$. Solution 3 was prepared by dissolving $0.054 \mathrm{~g}$ of $\mathrm{FeCL}_{3} \cdot 6 \mathrm{H}_{2} \mathrm{O}$ in $10 \mathrm{~mL}$ of distilled $\mathrm{H}_{2} \mathrm{O}$. The sample was prepared by mixing solution 1 $(8,200 \mu \mathrm{L})$ with solution $2(885 \mu \mathrm{L})$, solution $3(855 \mu \mathrm{L})$, and $30 \mu \mathrm{L}$ of EEP in succession. The resulting mixture was allowed to rest for $10 \mathrm{~min}$ at $20^{\circ} \mathrm{C}$, protected from light. Consequently, the absorbance at $593 \mathrm{~nm}$ was measured, each sample of propolis was measured five times. The standard curve was generated using a concentration of $3 \mathrm{mg}$ per $\mathrm{mL}$ of trolox $\left(\mathrm{r}^{2}=0.9975\right)$.

\subsection{Statistical analysis}

The data obtained was analyzed by means of a t-test and a one-way ANOVA in SAS (Statistical Analysis System) software. The multiple comparisons of means were performed via a 
Tukey test. Probability values smaller than 0.05 were accepted as statistically significant.

\section{Results and discussion}

\subsection{Flavonoid content}

Table 1 shows the total content of flavonoids in propolis, the amount of flavonoids ranged between 13 and $379 \mathrm{mg}$ per $\mathrm{g}$ of propolis. The highest content of flavonoids was found in El Acebuche $^{(21)}$, and León ${ }^{(25)}(\mathrm{P} \leq 0.05)$, followed by Los Galvanes ${ }^{(29)}$ and El Copal ${ }^{(14)}$. The least amount of flavonoids was found in Valle de Santiago ${ }^{(6)}$, Monte Valerio ${ }^{(8)}$, El Acebuche ${ }^{(19)}$ and Las Maravillas $^{(20)}(\mathrm{P} \leq 0.05)$; the others samples had average values.

Table 1. Municipality (the location of propolis collection), flavonoid, and phenolic content of EEP.

\begin{tabular}{|c|c|c|c|}
\hline Municipality & $\begin{array}{c}\text { Location of } \\
\text { propolis recollection }\end{array}$ & $\begin{array}{c}\text { Flavonoids } \\
(\mathrm{mg} / \mathrm{g} \text { of EEP) }\end{array}$ & $\begin{array}{c}\text { Phenols } \\
(\mathrm{mg} / \mathrm{g} \text { of EEP) }\end{array}$ \\
\hline Cortazar & San Isidro Calera ${ }^{(30)}$ & $130 \pm 2 g^{\text {hij }}$ & $105 \pm 2^{\text {no }}$ \\
\hline \multirow{6}{*}{$\begin{array}{l}\text { Dolores } \\
\text { Hidalgo }\end{array}$} & Dolores Hidalgo $^{(4)}$ & $150 \pm 4^{\mathrm{fgh}}$ & $179 \pm 1^{1 \mathrm{jk}}$ \\
\hline & Cerro Blanco $^{(9)}$ & $218 \pm 2^{\text {cde }}$ & $418 \pm 4^{\mathrm{b}}$ \\
\hline & Cerro Blanco ${ }^{(10)}$ & $110 \pm 6^{\mathrm{hijkl}}$ & $207 \pm 1^{\text {ghijk }}$ \\
\hline & Adjuntas del Rio(13) & $178 \pm 9^{\mathrm{ef}}$ & $413 \pm 7^{b c}$ \\
\hline & La Regadera ${ }^{(27)}$ & $220 \pm 1^{\mathrm{cd}}$ & $330 \pm 1^{\mathrm{e}}$ \\
\hline & La Regadera ${ }^{(28)}$ & $243 \pm 4^{\mathrm{bc}}$ & $317 \pm 7^{\text {ef }}$ \\
\hline Irapuato & El Copal ${ }^{(14)}$ & $232 \pm 2^{\mathrm{bc}}$ & $493 \pm 2^{\mathrm{a}}$ \\
\hline \multirow[t]{4}{*}{ León } & Santa Rita ${ }^{(16)}$ & $165 \pm 6^{\mathrm{fg}}$ & $348 \pm 3^{\mathrm{de}}$ \\
\hline & $\begin{array}{c}\text { San Cristóbal de las } \\
\text { Casas }^{(18)}\end{array}$ & $88 \pm 2^{\mathrm{jklm}}$ & $293 \pm 2^{\mathrm{f}}$ \\
\hline & Capellanía de Loeria ${ }^{(24)}$ & $182 \pm 3^{\text {def }}$ & $184 \pm 1^{1 \mathrm{kij}}$ \\
\hline & León ${ }^{(25)}$ & $347 \pm 2^{\mathrm{a}}$ & $438 \pm 5^{b}$ \\
\hline \multirow{2}{*}{$\begin{array}{c}\text { Purísima del } \\
\text { Rincón }\end{array}$} & El Manso $^{(15)}$ & $126 \pm 6^{\text {ghijk }}$ & $342 \pm 2^{\mathrm{de}}$ \\
\hline & El Barrial ${ }^{(17)}$ & $124 \pm 8^{\text {ghijk }}$ & $230 \pm 10^{\mathrm{hg}}$ \\
\hline \multirow[t]{3}{*}{ Romita } & San Pedro ${ }^{(2)}$ & $63 \pm 2^{\mathrm{mno}}$ & $139 \pm 1^{\mathrm{mn}}$ \\
\hline & San Clemente ${ }^{(3)}$ & $71 \pm 1^{\mathrm{lmn}}$ & $219 \pm 7^{\text {hig }}$ \\
\hline & Maravillas $^{(20)}$ & $26 \pm 3^{\text {op }}$ & $208 \pm 5^{\text {ghij }}$ \\
\hline San Felipe & Jaral de Berrio ${ }^{(26)}$ & $98 \pm 3^{\mathrm{ijklm}}$ & $94 \pm 6^{\mathrm{op}}$ \\
\hline $\begin{array}{l}\text { San Miguel } \\
\text { Allende }\end{array}$ & Los Galvanes ${ }^{(29)}$ & $269 \pm 4^{\mathrm{b}}$ & $377 \pm 2^{\text {cd }}$ \\
\hline Silao & Las Maravillas $^{(1)}$ & $153 \pm 2^{\mathrm{fg}}$ & $172 \pm 9^{\mathrm{lmk}}$ \\
\hline \multirow[t]{5}{*}{ Tarimoro } & La Noria ${ }^{(5)}$ & $88 \pm 10^{\mathrm{klm}}$ & $201 \pm 2^{\mathrm{hijk}}$ \\
\hline & El Acebuche ${ }^{(19)}$ & $22 \pm 5^{\text {op }}$ & $239 \pm 2^{g}$ \\
\hline & El Acebuche ${ }^{(21)}$ & $379 \pm 4^{\mathrm{a}}$ & $501 \pm 2^{\mathrm{a}}$ \\
\hline & El Terrero ${ }^{(22)}$ & $131 \pm 7^{\text {ghi }}$ & $152 \pm 8^{\mathrm{Im}}$ \\
\hline & El Terrero ${ }^{(23)}$ & $161 \pm 5^{\mathrm{fg}}$ & $153 \pm 2^{\mathrm{lm}}$ \\
\hline \multirow{5}{*}{$\begin{array}{l}\text { Valle de } \\
\text { Santiago }\end{array}$} & Valle de Santiago $^{(6)}$ & $22 \pm 8^{\text {op }}$ & $81 \pm 7^{\mathrm{op}}$ \\
\hline & Mesa de San Agustín ${ }^{(7)}$ & $31 \pm 11^{\text {nop }}$ & $69 \pm 4^{\mathrm{p}}$ \\
\hline & Monte Valerio ${ }^{(8)}$ & $13 \pm 2^{\mathrm{p}}$ & $82 \pm 6^{o p}$ \\
\hline & Monte Valerio $^{(11)}$ & $101 \pm 10^{\mathrm{ijklm}}$ & $212 \pm 10^{\text {higj }}$ \\
\hline & El Gavilán ${ }^{(12)}$ & $161 \pm 8^{\mathrm{fg}}$ & $412 \pm 1^{b c}$ \\
\hline
\end{tabular}

a-pMeans indexed with a different letter in the same column are statistically different $(\mathrm{P} \leq 0.05)$. Measurements were performed five times; means and standard deviations are indicated.
Some studies report from 8 to $188 \mathrm{mg}$ of flavonoids per $\mathrm{g}$ of propolis in China, India, Macedonia, and Iran (Ahn et al., 2007; Laskar et al., 2010; Lagouri et al., 2013). Kumazawa et al. (2004) and Laskar et al. (2010) reported maximum values of $200 \mathrm{mg}$ of flavonoids per $\mathrm{g}$ of propolis in USA, Brazil, Thailand, and New Zealand. The variation of flavonoid content found in propolis of state of Guanajuato was $40 \%$ higher compared with others ( 379 vs. $200 \mathrm{mg}$ per $\mathrm{g}$ of propolis). The quantity of flavonoids found in propolis can be attributed to the vegetation where honey bees gather propolis (Ahn et al., 2007). These results show a high content of flavonoids in propolis collected in the state of Guanajuato.

\subsection{Phenolic content}

Table 1 shows the total content of phenols in propolis, the amount of these compounds varied from 68 to $500 \mathrm{mg}$ per $\mathrm{g}$ of propolis. The highest content of phenolic compounds was found in propolis collected from El Acebuche ${ }^{(21)}$ and El Copal ${ }^{(14)}$ $(\mathrm{P} \leq 0.05)$, followed by Cerro Blanco ${ }^{(9)}$ and León ${ }^{(25)}$. The lowest concentrations of these compounds were found in samples from the Valle de Santiago ${ }^{(6)}$, Mesa de San Agustín ${ }^{(7)}$, Monte Valerio $^{(8)}$ and Jaral de Berrio ${ }^{(26)}(\mathrm{P} \leq 0.05)$; the other samples had average values.

Ahn et al. (2007), Moreira et al. (2008) and Lagouri et al. (2013) reported levels of phenols from 42.9 to $329.0 \mathrm{mg}$ per $\mathrm{g}$ of propolis in China, Macedonia, and Portugal. Similarly, Kumazawa et al. (2004) and Lagouri et al. (2013) reported maximum values of phenolic compounds in propolis from Argentina, Australia, Brazil, Bulgaria and Chile with $298 \mathrm{mg}$ of phenolic compounds per $g$ of propolis. In India, quantities lower than $160 \mathrm{mg}$ of phenols per $\mathrm{g}$ of propolis were reported. In the case of Guanajuato, the variation in phenolic compounds found were $35 \%$ higher that the amounts reported in countries outside of Mexico (Ahn et al., 2007; Moreira et al., 2008; Laskar et al., 2010; Lagouri et al., 2013).

\subsection{Antioxidant capacity (the DPPH• method)}

Figure 2 shows the antioxidant capacity of the propolis determined by the DPPH $\bullet$ method. The propolis were presented an antioxidant range from 39 to 54 of TEAC per $\mathrm{g}$ of propolis. Propolis collected from Jaral de Berrio ${ }^{(26)}$ and San Isidro Calera ${ }^{(30)}$ showed an antioxidant capacity similar to BHT (54, 53 vs. 56 TEAC per g of propolis); these values were significantly higher $(\mathrm{P} \leq 0.05)$ than the average $(47 \mathrm{TEAC}$ per $\mathrm{g}$ of propolis). Propolis with lowest antioxidant capacity were those from El Terrero ${ }^{(22)}$ (39 TEAC per $\mathrm{g}$ of propolis, $\mathrm{P} \leq 0.05$ ). Analyzing these data in a holistic manner, a negative correlation $(\mathrm{P} \leq 0.05)$ was found between flavonoids $(-0.478)$, phenols $(-0.413)$ and the decrease in DPPH $\bullet$ values. Therefore, more flavonoids and phenolics compounds in propolis can be increased their antioxidant power determined with this method.

$\mathrm{DPPH} \bullet$ is a stable, purple colored radical which changes to pale yellow when it captures free radicals (Kumazawa et al., 2004). The antioxidant effect of propolis was reported in trolox equivalent antioxidant capacity (TEAC) per g of propolis. Trolox is an analog of vitamin $\mathrm{E}$, a standardized measure of its activity 
is trolox equivalent antioxidant capacity. All propolis showed an antioxidant capacity greater than 39 TEAC; 17 samples exceeded 47 TEAC, and samples 26 and 30 exceeded 53 TEAC with an effect similar to that of BHT used as a reference with 57 TEAC.

In the experiment, the propolis with the greater antioxidant capacity were not the ones that contained the highest amounts of flavonoids and phenols (Table 1). In various studies, the propolis were evaluated under the DPPH• method. A correlation between the amount of flavonoids and phenols compounds with their antioxidant capacity (Ahn et al., 2007; Lagouri et al., 2013) was reported, in this study the same effect was observed. The propolis samples with most flavonoids and phenols show the highest antioxidant effect. The amount of flavonoids and phenols reflect the antioxidant activity of propolis in our study. Being naturally occurring compounds, oxidation tests should be carried out in order to determine their antioxidant capacity and the effect of the type and amount of active compounds present in propolis (Sulaiman et al., 2011).

The biological activity of propolis is related to the amount of flavonoids and phenols, responsible for its antioxidant capacity (Hegazi et al., 2000). The extracts of flavonoids and phenols, obtained and quantified under the procedures described here, were determinant enough to correlate the contents of both bioactive compounds and the antioxidant capacity directly. Therefore, it is necessary to identify and quantify these compounds in further investigations by applying more specific techniques. Kumazawa et al. $(2004,2010)$ reported that the antioxidant power of propolis is due to the content of caffeic acid and kaempferol.

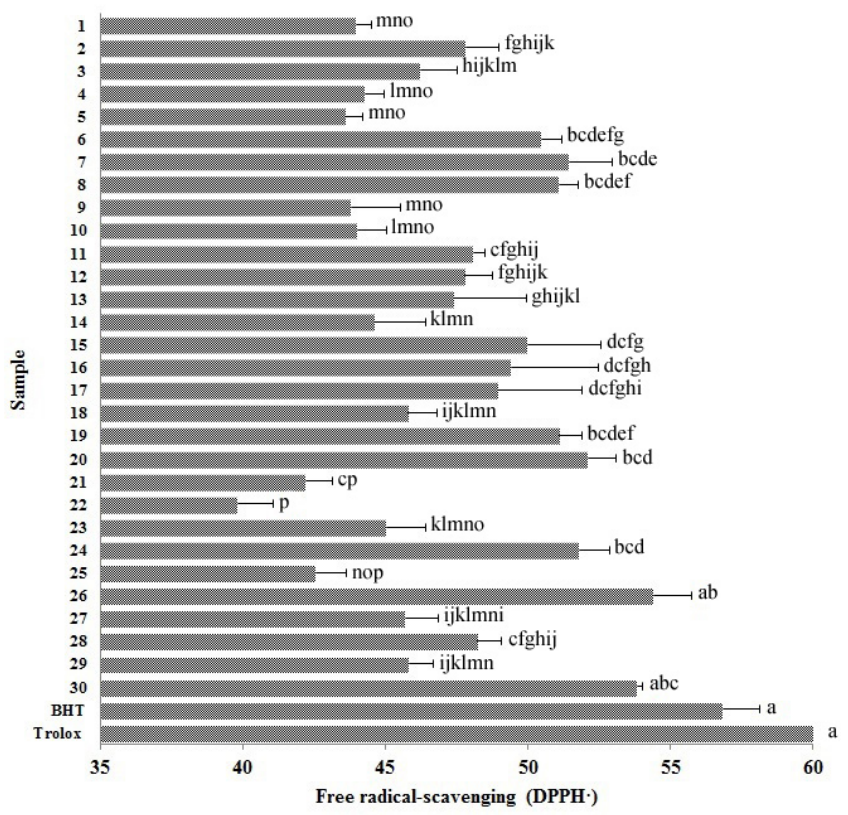

Figure 2. Activity of the DPPH • radical in 30 samples of EEP collected from the beekeeping areas of Guanajuato, Mexico. BHT, butylhydroxytoluene; trolox, 6-hydroxy-2,5,7,8-tetramethylchroman2-carboxylic acid. Measurements were performed five times; mean and standard deviations are indicated. ${ }^{a-p}$ Means indexed with a different letter in the same column are statistically different $(\mathrm{P} \leq 0.05)$.
Hegazi et al. (2000) mention that the effect is due to galangin, benzyl caffeate, and pinocembrin.

The antioxidant properties of propolis are related to the diversity of the geographical areas, the plants in the area, the time of year, the type of bees, and only some of them have an excellent antioxidant quality (Huang et al., 2014; Miguel et al., 2014). Clearly, Guanajuato propolis contains different bioactive compounds or greater amounts of these compared to those reported in different locations and countries. The different concentrations of bioactive compounds in propolis might be influenced by the vegetation in the sampling areas.

\subsection{Antioxidant capacity (the FRAP• method)}

Figure 3 shows the antioxidant capacity of the propolis determined by the FRAP• method. The range of the antioxidant capacity obtained was from 32.0 to 1983.9 TEAC per $g$ of propolis (from 1.3 to $79 \%$ ). Propolis samples collected from La Regadera ${ }^{(27)}$ had the highest antioxidant capacity of all (1983 of TEAC per $\mathrm{g}$ of propolis, $\mathrm{P} \leq 0.05$ ), followed by samples from Los Galvanes $^{(29)}$, La Regadera ${ }^{(28)}$, and Adjuntas del Rio ${ }^{(13)}$ (1832, 1817 and 1729 TEAC, respectively). Propolis from El Barrial ${ }^{(17)}$, Dolores Hidalgo $^{(4)}$, Santa Rita ${ }^{(16)}$, Valle de Santiago ${ }^{(6)}$, and Jaral de Berrio $^{(26)}$ presented an intermediate antioxidant capacity (1538, 1244, 1161, 1157 and 1130 TEAC per $g$ of propolis). Propolis samples with the lowest antioxidant capacity were those from León ${ }^{(25)}$, Maravillas ${ }^{(20)}$, Capellanía de Loeria ${ }^{(24)}$, El Terrero ${ }^{(22)}$, San Cristóbal de las Casas ${ }^{(18)}$ and Monte Valerio ${ }^{(8)}$, $(\mathrm{P} \leq 0.05)(31,37,111,258,242$ and 133 , TEAC per $\mathrm{g}$ of propolis,

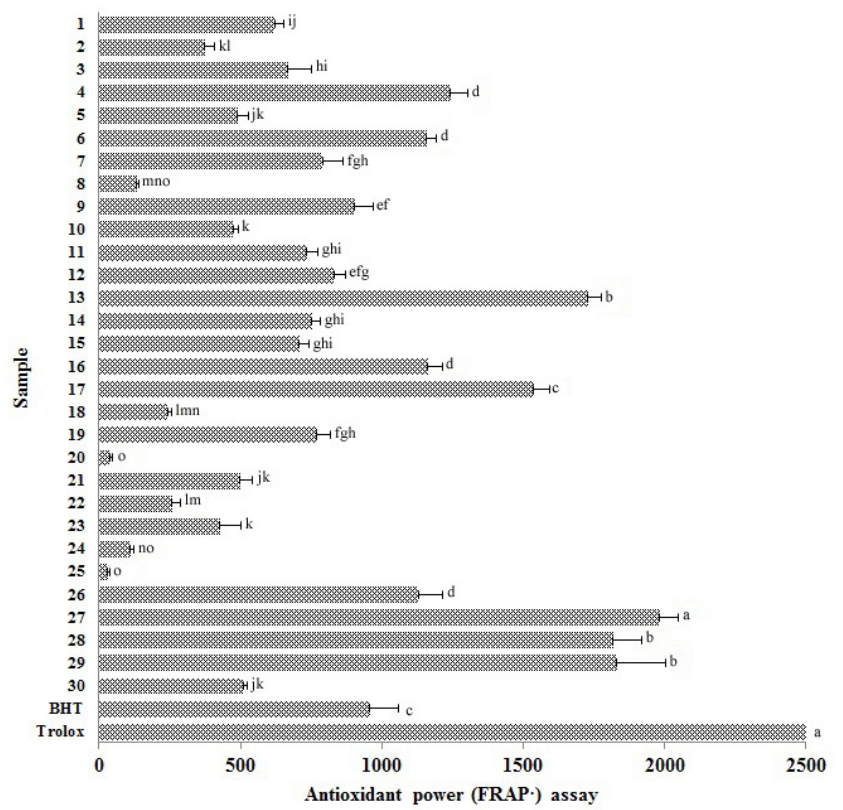

Figure 3. Antioxidant activity measured by FRAP• assay in 30 samples of EEP collected from the beekeeping areas of Guanajuato, Mexico. BHT, butylhydroxytoluene; trolox, 6-hydroxy-2,5,7,8-tetramethylchroman-2carboxylic acid. Measurements were performed five times; means and standard deviations are indicated. ${ }^{\mathrm{a}-\mathrm{o}}$ Means indexed with a different letter in the same column are statistically different $(\mathrm{P} \leq 0.05)$. 
$\mathrm{P} \leq 0.05)$. Analyzing the data in a holistic manner, a positive correlation $(\mathrm{P} \leq 0.05)$ was found between flavonoids (0.222), phenols (0.238), and their antioxidant capacity.

The reducing power of a component can serve as an indicator of its antioxidant capacity. The presence of an antioxidant in propolis causes the reduction of complex ferrocyanide $\left(\mathrm{Fe}^{3}+\right)$ to its ferrous form $\left(\mathrm{Fe}^{2}+\right)$ to a longitude of $593 \mathrm{~nm}$. When the concentration of antioxidants in propolis increases, the absorbance increases (Moreira et al., 2008). The results indicate that some propolis (Adjuntas del Rio ${ }^{(13)}$, La Regadera ${ }^{(27)}$, La Regadera ${ }^{(28)}$ and Los Galvanes ${ }^{(29)}$ ) showed activity higher than 1700 TEAC per $g$ of propolis, higher that of BHT, which only obtained 958 TEAC. Propolis with the lowest reducing capacity were from Monte Valerio $^{(8)}$, Maravillas ${ }^{(20)}$, Capellanía de Loeria ${ }^{(24)}$ and León ${ }^{(25)}$.

In this method, the amount of phenols and flavonoids in propolis does not reflect their antioxidant capacity (Sulaiman et al., 2011). Therefore, additional tests are to be performed in order to determine their effects. Propolis with highest antioxidant capacity has been linked to kaempferol and phenethyl (Kumazawa et al., 2010; Lagouri et al., 2013). In the present experiment, the antioxidant capacity of propolis determined by the FRAP• assay was standardized with trolox equivalents as a point of reference. In other studies, however, results are reported as $\mathrm{IC}^{50}$, a measurement unit referring to the prepared solution; this can complicate the comparison of results between different experiments (Lagouri et al., 2013). In this investigation, the $\mathrm{IC}^{50}$ value for $\mathrm{BHT}$ was $38.3 \%$, the range for propolis with the highest reducing capacity was 69.2 to 79.4 (the average of $73.6 \%$ ) while the $\mathrm{IC}^{50}$ value for propolis with the lowest reducing capacity was $3.6 \%$.

\section{Conclusions}

Propolis from the state of Guanajuato contain a high contain in flavonoids from 13 to $379 \mathrm{mg}$ and phenols from 68 to $500 \mathrm{mg}$ per $g$ of propolis with a lot of variation depending on its origin. The antioxidant capacity of propolis varies depending on the evaluation technique used. Guanajuato propolis can be a good source of antioxidants for food supplements. However, it is essential to identify the main active compounds individually by means of strict quantification techniques and to determine their biological activity.

\section{Acknowledgements}

The authors would like to express their gratitude to "Consejo de Ciencia y Tecnología del Estado de Guanajuato” (CONCYTEG) for the financial support granted to the research project 114/2015. Moreover, we acknowledge the University of Guanajuato (DAIP) for the financial support received for Project number 15 of the Institutional Grant for Strengthening Academic Excellence 2015.

\section{References}

Ahn, M., Kumazawa, S., Usui, Y., Nakamura, J., Matsuka, M., Zhu, F., \& Nakayama, T. (2007). Antioxidant activity and constituents of propolis collected in various areas of China. Food Chemistry, 101(4), 1383-1392. http://dx.doi.org/10.1016/j.foodchem.2006.03.045.
Attia, A. A., ElMazoudy, R. H., \& El-Shenawy, N. S. (2012). Antioxidant role of propolis extract against oxidative damage of testicular tissue induced by insecticide chlorpyrifos in rats. Pesticide Biochemistry and Physiology, 103(2), 87-93. http://dx.doi.org/10.1016/j.pestbp.2012.04.002.

Bennett, J. (1999). Free radicals, oxidative stress and the origin of Parkinson's. Journal of the Neurological Sciences, 170(2), 75-76. http://dx.doi.org/10.1016/S0022-510X(99)00191-4. PMid:10561521.

Frozza, C. O. D., Silvestrin, C. C. G., Gambato, G., Denize, O. M., Salvador, M., \& Moura, F. F. P. (2013). Chemical characterization, antioxidant and cytotoxic activities of Brazilian red propolis. Food and Chemical Toxicology, 52, 137-142. http://dx.doi.org/10.1016/j. fct.2012.11.013. PMid:23174518.

Hegazi, A. G., Abd El Hady, F. K., \& Abd Allah, F. A. (2000). Chemical composition and antimicrobial activity of European propolis. Zeitschrift für Naturforschung, 55(1-2), 70-75. PMid:10739103.

Huang, S., Zhang, C.-P., Wang, K., Li, G., \& Hu, F.-L. (2014). Recent advances in the chemical composition of propolis. Molecules, 19(12), 19610-19632. http://dx.doi.org/10.3390/molecules191219610. PMid:25432012.

Kouidhi, B., Zmantar, T., \& Bakhrouf, A. (2010). Anti-cariogenic and anti-biofilms activity of Tunisian propolis extract and its potential protective effect against cancer cells proliferation. Anaerobe, 16(6), 566-571. http://dx.doi.org/10.1016/j.anaerobe.2010.09.005. PMid:20934525.

Kumazawa, S., Ahn, M. R., Fujimoto, T., \& Kato, M. (2010). Radicalscavenging activity and phenolic constituents of propolis from different regions of Argentina. Natural Product Research, 24(9), 804-812. http://dx.doi.org/10.1080/14786410802615270. PMid:20461626.

Kumazawa, S., Hamasaka, T., \& Nakayama, T. (2004). Antioxidant activity of propolis of various geographic origins. Food Chemistry, 84(3), 329-339. http://dx.doi.org/10.1016/S0308-8146(03)00216-4.

Lagouri, V., Prasianaki, D., \& Krysta, F. (2013). Antioxidant properties and phenolic composition of Greek propolis extracts. International Journal of Food Properties, 17(3), 511-522. http://dx.doi.org/10.108 0/10942912.2012.654561.

Laskar, R. A., Sk, I., Roy, N., \& Begum, N. A. (2010). Antioxidant activity of Indian propolis and its chemical constituents. Food Chemistry, 122(1), 233-237. http://dx.doi.org/10.1016/j.foodchem.2010.02.068.

Lei, X. G., Cheng, W.-H., \& McClung, J. P. (2007). Metabolic regulation and function of glutathione peroxidase-1. Annual Review of Nutrition, 27(1), 41-61. http://dx.doi.org/10.1146/annurev.nutr.27.061406.093716. PMid:17465855.

Lustosa, S. R., Galindo, A. B., Nunes, L. C. C., Randau, K. P., \& Rolim, P. J. No. (2008). Propolis: atualizações sobre a química e a farmacologia. Brazilian Journal of Pharmacognosy, 18(3), 447-454. http://dx.doi. org/10.1590/S0102-695X2008000300020.

Maxwell, S. R., \& Lip, G. Y. (1997). Free radicals and antioxidants in cardiovascular disease. British Journal of Clinical Pharmacology, 44(4), 307-317. PMid:9354304.

McCay, P. B. (1985). Vitamin E: interactions with free radicals and ascorbate. Annual Review of Nutrition, 5(1), 323-340. http://dx.doi. org/10.1146/annurev.nu.05.070185.001543. PMid:2992548.

Miguel, M. G., Nunes, S., Dandlen, S. A., Cavaco, A. M., \& Antunes, M. D. (2014). Phenols, flavonoids and antioxidant activity of aqueous and methanolic extracts of propolis (Apis mellifera L.) from Algarve, south Portugal. Food Science and Technology, 34(1), 16-23. http:// dx.doi.org/10.1590/S0101-20612014000100002.

Moreira, L., Dias, L. G., Pereira, J. A., \& Estevinho, L. (2008). Antioxidant properties, total phenols and pollen analysis of propolis samples from 
portugal. Food and Chemical Toxicology, 46(11), 3482-3485. http:// dx.doi.org/10.1016/j.fct.2008.08.025. PMid:18804144.

Padmavathi, R., Senthilnathan, P., Chodon, D., \& Sakthisekaran, D. (2006). Therapeutic effect of paclitaxel and propolis on lipid peroxidation and antioxidant system in 7,12 dimethyl benz(a) anthracene-induced breast cancer in female Sprague Dawley Rats. Life Sciences, 78(24), 2820-2825. http://dx.doi.org/10.1016/j. lfs.2005.11.005. PMid:16375927.

Silva, F. C., Rodrigues, F. R., Matias, A. S., Thomazini, M., Carvalho, B. J., Pittia, P., \& Favaro-Trindade, C. S. (2013). Assessment of production efficiency, physicochemical properties and storage stability of spray-dried propolis, a natural food additive, using gum arabic and osa starch-based carrier systems. Food and Bioproducts Processing, 91(1), 28-36. http://dx.doi.org/10.1016/j.fbp.2012.08.006.

Simone-Finstrom, M., \& Spivak, M. (2010). Propolis and bee health: the natural history and significance of resin use by honey bees. Apidologie, 41(3), 295-311. http://dx.doi.org/10.1051/apido/2010016.

Sulaiman, G. M., Sammarrae, K. W. A., Ad'hiah, A. H., Zucchetti, M., Frapolli, R., Bello, E., Erba, E., D’Incalci, M., \& Bagnati, R. (2011). Chemical characterization of Iraqi propolis samples and assessing their antioxidant potentials. Food and Chemical Toxicology, 49(9), 2415-2421. http://dx.doi.org/10.1016/j.fct.2011.06.060. PMid:21723909.

Valente, M. J., Baltazar, A. F., Henrique, R., Estevinho, L., \& Carvalho, M. (2011). Biological activities of Portuguese propolis: protection against free radical-induced erythrocyte damage and inhibition of human renal cancer cell growth in vitro. Food and Chemical Toxicology, 49(1), 86-92. http://dx.doi.org/10.1016/j.fct.2010.10.001. PMid:20934479.

Vera-Ramirez, L., Sanchez-Rovira, P., Ramirez-Tortosa, M. R., RamirezTortosa, C. L., Granados-Principal, S., Lorente, J. A., \& Quiles, J. L. (2011). Free radicals in breast carcinogenesis, breast cancer progression, and cancer stem cells. Biological bases to develop oxidative-based therapies. Critical Reviews in Oncology/Hematology, 80(3), 347-368. http://dx.doi.org/10.1016/j.critrevonc.2011.01.004. PMid:21288735.

Vongsak, B., Kongkiatpaiboon, S., Jaisamut, S., Machana, S., \& Pattarapanich, C. (2015). In vitro alpha-glucosidase inhibition and free-radical scavenging activity of propolis from Thai stingless bees in mangosteen orchard. Brazilian Journal of Pharmacognosy, 25(5), 445-450. http://dx.doi.org/10.1016/j.bjp.2015.07.004.

Wojtunik-Kulesza, K. A., Oniszczuk, A., Oniszczuk, T., \& WaksmundzkaHajnos, M. (2016). The influence of common free radicals and antioxidants on the development of Alzheimer's Disease. Biomedicine and Pharmacotherapy, 78(1), 39-49. http://dx.doi.org/10.1016/j. biopha.2015.12.024. PMid:26898423.

Wu, J., Omene, C., Karkoszka, J., Bosland, M., Eckard, J., Klein, C. B., \& Frenkel, K. (2011). Caffeic acid phenethyl ester (CAPE), derived from a honeybee product propolis, exhibits a diversity of anti-tumor effects in pre-clinical models of human breast cancer. Cancer Letters, 308(1), 43-53. http://dx.doi.org/10.1016/j.canlet.2011.04.012. PMid:21570765. 